\title{
Subsidies on Investments in the EU Member States
}

\author{
J. Svoboda, J. Lososová, R. Zdeněk \\ Faculty of Economics, University of South Bohemia, České Budějovice, Czech Republic
}

\begin{abstract}
The article compares the investment subsidies in agriculture within the EU member states throughout the period of $2004-2013$ based on the FADN database. Low investment level affects the cost and efficiency of agricultural production and thus the overall competitiveness of agricultural production. European programs providing support for the investments for agriculture aim at improving agricultural competitiveness. Development of subsidies on investment, property and Farm Net Income adjusted to economic size of enterprise by correlation analysis is compared in every EU country. Using cluster analysis, the member states were divided into groups according to subsidies on investments, their share in gross investment and the share of gross investments in fixed assets. The relationship between subsidies on investments and gross investment ranges from middle to higher dependency. The amount of subsidies on investments does not significantly affect the amount of current Farm Net Income.
\end{abstract}

\section{Keywords}

Subsidies on investments, gross investment, farm net income, fixed assets, economic size.

Svoboda, J., Lososová, J. and Zdeněk, R. (2016) "Subsidies on Investments in the EU Member States", AGRIS on-line Papers in Economics and Informatics, Vol. 8, No. 4, pp. 153 - 162. ISSN 1804-1930. DOI 10.7160/aol.2016.080414.

\section{Introduction}

In the Rural Development Program for the period 2014-2020, the European Commission has set three main objectives for the future CAP: viable food production, sustainable management of natural resources and climate policies and balanced territorial development. Six priorities have been defined: the promotion of knowledge transfer in agriculture and forestry, improvement of agricultural competitiveness and viability of farming and forestry, support for the food chain organization and risk management, restoration, protection and maintenance of the ecosystems dependent on agriculture and forestry, support of the efficient resource usage and transition to the low carbon economy in the agri-food sector and forestry, the promotion of social inclusion, poverty reduction and economic development of rural areas. Fulfilment of these objectives requires mobilizing both European and national resources. Strengthening the competitiveness of agriculture requires primarily increasing the labour productivity, which is not possible without additional investments.

The investment issue is important because the current farm production is a function of several inputs, including the current level of capital, which depends on past investment decisions. Annual investment decisions affect both current and future production. Thus, any policy that increases investment will influence farm output for some years into the future (OECD, 2001).

In the program period 2007 - 2013 the Member States drew the resources to support agricultural and rural development from EAFRD (Agricultural Fund for Rural Development) and also for the current programming period it is possible to draw resources for investment in agriculture through this fund based on the approved Rural Development Programs for the years 2014 - 2020.

A lot of works deal with effects of various types of subsidies on investment (Viaggi, Raggi, and Paloma, 2011; Rizov, Pokrivcak, and Ciaian, 2013; O'Toole and Hennessy, 2015; Michalek, Ciaian, and Kancs 2016). The major concern of evaluation studies is assuring the causality between programme measures and estimated effects (Bergschmidt, 2009; Blandford et al., 2010; Margarian et al., 2010). Programme effects might show time lags or even underlie other dynamics. Since establishing agricultural investments often requires long timespans (Hoffmann, et al. (1997), Forstner (2000) and Bradley et al. (2010) point out that chosen observation periods might be too 
short to be able to measure the full implementation success of investments. Findings in the literature focus on the effects of coupled subsidies in narrowly defined agricultural industries. Latruffe et al. (2009) find a negative impact of coupled CAP subsidies on the efficiency of French farms specialised in cereals, oilseeds and beef production. Lakner (2009) shows, that the agrienvironmental payments and investment programmes have a negative effect on the efficiency of organic dairy farms in Germany. Yee et al. (2004) find a positive relation between the TFP of US farms and public expenditure on investment in research, extension and infrastructure. Mary (2012) estimates the impact of various types of CAP subsidies on the efficiency of French crop farms. Targeted coupled subsidies that are not automatic but subject to project approval, such as investment and environmental measures, are found to have no significant impact on productivity. The aim of paper Kirchweger, S., \& Kantelhardt, J. (2015) is to identify the effects of the Austrian farminvestment support programme on structural change in agriculture. The authors say that, the intensification effect of the European investment programme is in contrast to the goals of the European agri-environmental schemes, even though both are part of the European RD programme.

According to Richardson (2000) and Shucksmith et al. (2005) more policy focus is required on places instead of sectors, acknowledging the heterogeneity of rural regions as complex economic, cultural and natural location. This is in line with OECD recommendations which promoted a paradigm shift in rural development in response to the observed heterogeneity of challenges for rural regions. The OECD calls for a place-based approach with stronger emphasis on investments and the valorisation of local assets (OECD, 2006).

Sckokai and Moro (2009) quantifies the impact of farm policies on investment and output decisions, with specific reference to the CAP arable crop regime. The policy impact on farm investment is not strongly reflected in a positive impact on farm output, since the investment effects tend to be quite small.

Article of authors Zasada, et al. (2015) is clarifying the interactions between capital investments and capacity building, and on the relevance of the regional conditions and factor endowments in determining rural development priorities. For the new programming period 2014-2020 improved conditions towards the recognition of development potentials through a multi- level governance process have been established, which also allow space for more first place-based initiatives and projects. Lucian (2014) says that the absorption level of European funds for the financial period 2007-2013 was low for several reasons: lack of strategic vision for programming development, poor quality of projects, excessive bureaucracy, lack of optimization of financial flows etc. For the financial programming period 2014-2020, the European Commission will improve the absorption of EU funds.

The objective of this report is to analyse the investment subsidies in the EU in the period 2004 - 2013, which is based on the comparison of selected economic indicators and to find the connections and links between economic indicators and investment subsidies.

\section{Materials and methods}

In this report there are used calculations based on the database FADN sample survey, the standard output (SO) within the 2004-2013 period. The SO represents an average monetary value of agricultural production in the prices of agricultural producers for each commodity in the region. The SO is calculated, by the Member States, per hectare or per livestock unit using basic data application for the period of 5 consecutive years. The SO of the agricultural enterprise is calculated as a sum of the SO of farm livestock. The SO coefficient is expressed crops and livestock. The large number of items not only reflects the diversity of agriculture in the EU but also indicates the level of mandatory surveys required for the comprehensiveness and reliability of the outputs.

Of the many recorded indicators there were chosen these items which are relevant to the issue and also are linked to investments. Specifically, these are the following indicators:

- Economic size-ESU (code SE 005).

- Subsidies on investments-EURO (SE 406)

- Farm Net Income-EURO (SE 420) FNI: Remuneration to fixed factors of production of the farm (work, land and capital) and remuneration to the entrepreneurs risks (loss/profit) in the accounting year.

- Total fixed assets-EURO (SE 441): Agricultural land and farm buildings and forest capital + Buildings + Machinery and equipment + Breeding livestock. 
- Gross Investment-EURO (SE 516): Purchases (exp. land, improvements, machinery, building) - Sales of Fixed assets + breeding livestock change of valuation.

For the reason of higher data comparability, the indicators were recalculated to the economic size of farms thereby the size of particular agricultural farms in states were taken into account.

In this article was used annual growth rate $\sqrt[n-1]{\frac{E V}{B V}}$ and for the reasons zero beginning value average annual increment $\frac{E V-B V}{n-1}$ where $E V$ are the ending value, $B V$ are the beginning value and $n$ are the number of periods.

Based on the data, processed by cluster analysis, a multi-variable statistial method dividing the large groups of observation into smaller and more homogeneous groups could be carried out. This method can be applied similarly to the classification of EU Member States according to the economic performance of farms (Giannakis and Bruggeman, 2015) the clustering process can be roughly divided into three categories - hierarchical, non-hierarchical and a two-stage category. Ward's method was used in this article. Ward's method joins two clusters, $A$ and $B$, that minimize the increase in the sum of squares of error within a cluster, IAB (Rencher (2002), Řezanková, Húsek and Snášel, (2009)),

$I_{A B}=\frac{n_{A} n_{B}}{n_{A}+n_{B}}\left(\overline{\mathbf{y}}_{A}-\overline{\mathbf{y}}_{B}\right)^{T}\left(\overline{\mathbf{y}}_{A}-\overline{\mathbf{y}}_{B}\right)$.

where $n_{A}, n_{B}$ are the numbers of points in $A, B$; $\overline{\mathbf{y}}_{A}, \overline{\mathbf{y}}_{B}$ are centroids of $\mathrm{A}$ and $\mathrm{B}$, respectively. As a distance function is used Eucliean distance between two vectors $\mathbf{x}=\left(x_{1}, x_{2}, \ldots, x_{p}\right)^{T}$ and $\mathbf{y}=\left(y_{1}, y_{2}, \ldots, y_{p}\right)^{T}$, defined as (Rencher, 2002)

$d(\mathbf{x}, \mathbf{y})=\sqrt{(\mathbf{x}-\mathbf{y})^{T}(\mathbf{x}-\mathbf{y})}$.

Dividing EU states into groups which allows for a more understandable assessment and defines the aim of its evaluation (Svoboda, Lososová and Zdeněk, 2015). The commentary of these groups includes basic descriptive statistical characteristic. The next part contains the description of the relationship between defined and relative indices by the methods of correlation and regression analysis (Farm Net Income/ Subsidies on investments, Total fixed assets/ Subsidies on investments, Gross Investment/ Subsidies on investments).

\section{Results and discussion}

The development of the subsidies on investments was monitored on the basis of FADN data converted into economic size (ESU) - see Table 1. They are listed their absolute value and the average annual increment for the period of monitoring. Differences in the amount of investment subsidies are considerably between countries, some NMS started to support investments in agriculture to during the reporting period. Of the EU 15 countries are most encouraged investment in agriculture in Luxembourg and the lowest in Sweden.

During the period 2004-2013, the average increment of subsidies on investment in the EU was $0.25 € /$ ESU per annum. Luxembourg (3.62 €/ESU), Lithuania (2.88), Bulgaria (2.55), Malta (1.69), Portugal (1.45), Slovakia (1.39), Czech Republic (1.29) show the highest average increment of subsidies on investment per annum. On the contrary, the highest decrease in subsidies on investment was recorded in Slovenia (-7.2 €/ESU per annum), Latvia (-6.13), Estonia $(-0.67)$, Romania (-0.59), Greece $(-0.31)$, Ireland $(-0.24)$, France $(-0.11)$ and Sweden $(-0.01)$ (Table 1).

EU Member States were divided using cluster analysis into 4 groups, which have similar development investment grants during the period (Figure 1).

Group 1 (Belgium, Poland, UK, France, Finland), where investment subsidies recalculated to the economic size of a company approaches the EU average and grow in time (except France). The average growth rate of investment subsidies is the highest in Poland (36\% annually), Finland (18\%) and Belgium (15\% annually).

Group 2 (Denmark, Netherlands, Sweden, Germany, Greece, Spain, Italy) is characterized by below-average investment subsidies recalculated to the economic size of a company or in individual years distinct divergences are evident in the size of investment subsidies (Greece), in Sweden investment subsidies have been zero recently. The average growth rate is the highest in the Netherlands $(53 \%)$ and Germany $(15 \%)$, Greece shows the average inter-annual decrease.

Group 3 (Cyprus, Hungary, the CR, Portugal, Malta, Austria, Slovakia) has above- growth average investment subsidies, and the $\mathrm{CR}$ shows the highest (by $20 \%$ on the average annually), Malta and Slovakia proves distinct divergences in individual years and average decrease can be 


\begin{tabular}{|c|c|c|c|c|c|c|c|c|c|c|c|}
\hline & 2004 & 2005 & 2006 & 2007 & 2008 & 2009 & 2010 & 2011 & 2012 & 2013 & $\begin{array}{c}\text { Average } \\
\text { increment }\end{array}$ \\
\hline Belgium & 2.63 & 3.02 & 4.06 & 5.11 & 7.82 & 8.84 & 11.62 & 9.94 & 11.96 & 9.45 & 0.76 \\
\hline Bulgaria & & & & 4.06 & 2.07 & 4.03 & 2.55 & 5.93 & 12.23 & 19.36 & 2.55 \\
\hline Cyprus & 0 & 0 & 7.57 & 1.52 & 10.75 & 41.65 & 20.03 & 16.01 & 22.58 & 6.65 & 0.74 \\
\hline Czech Republic & 2.76 & 5.00 & 5.60 & 8.38 & 10.21 & 15.89 & 17.94 & 35.32 & 27.02 & 14.34 & 1.29 \\
\hline Denmark & 1.25 & 0.92 & 0.88 & 0.56 & 0.72 & 0.17 & 0.53 & 0.13 & 1.89 & 2.48 & 0.14 \\
\hline Greece & 4.68 & 1.57 & 11.48 & 7.06 & 5.41 & 3.33 & 1.70 & 0.92 & 0.76 & 1.92 & -0.31 \\
\hline Spain & 1.68 & 3.08 & 4.58 & 2.01 & 5.17 & 4.33 & 4.08 & 5.13 & 4.11 & 2.67 & 0.11 \\
\hline Estonia & 63.73 & 33.23 & 14.63 & 15.44 & 138.04 & 77.48 & 42.32 & 54.29 & 59.01 & 57.73 & -0.67 \\
\hline France & 9.54 & 9.29 & 10.93 & 8.58 & 9.05 & 7.36 & 8.64 & 7.98 & 8.64 & 8.57 & -0.11 \\
\hline Croatia & & & & & & & & & & 0 & \\
\hline Lithuania & 33.58 & 93.94 & 190.67 & 62.65 & 125.10 & 220.93 & 168.63 & 148.84 & 94.26 & 59.51 & 2.88 \\
\hline Luxembourg & 61.74 & 72.85 & 76.97 & 94.24 & 83.03 & 81.12 & 79.70 & 81.86 & 96.54 & 94.33 & 3.62 \\
\hline Latvia & 55.16 & 79.88 & 67.62 & 86.76 & 84.08 & 51.74 & 42.50 & 118.10 & 0 & 0 & -6.13 \\
\hline Malta & 0 & 3.92 & 7.70 & 0.27 & 6.33 & 0 & 56.47 & 47.22 & 19.51 & 15.18 & 1.69 \\
\hline Netherlands & 0.04 & 1.99 & 0.63 & 0.26 & 0.30 & 0.38 & 1.04 & 0.26 & 0.87 & 1.81 & 0.20 \\
\hline Austria & 22.17 & 24.33 & 28.76 & 22.45 & 34.37 & 41.44 & 34.74 & 35.22 & 27.67 & 23.30 & 0.13 \\
\hline Poland & 0 & 0.93 & 2.22 & 7.73 & 11.65 & 7.58 & 10.71 & 10.72 & 11.06 & 11.08 & 1.23 \\
\hline Portugal & 21.06 & 26.67 & 26.59 & 10.79 & 9.65 & 15.79 & 18.26 & 33.13 & 34.48 & 34.12 & 1.45 \\
\hline Romania & & & & 4.23 & 3.20 & 2.80 & 0.65 & 1.32 & 0.34 & 0.71 & -0.59 \\
\hline
\end{tabular}

Source: FADN

Table 1: Investment subsidies (in $€ / E S U$ ).

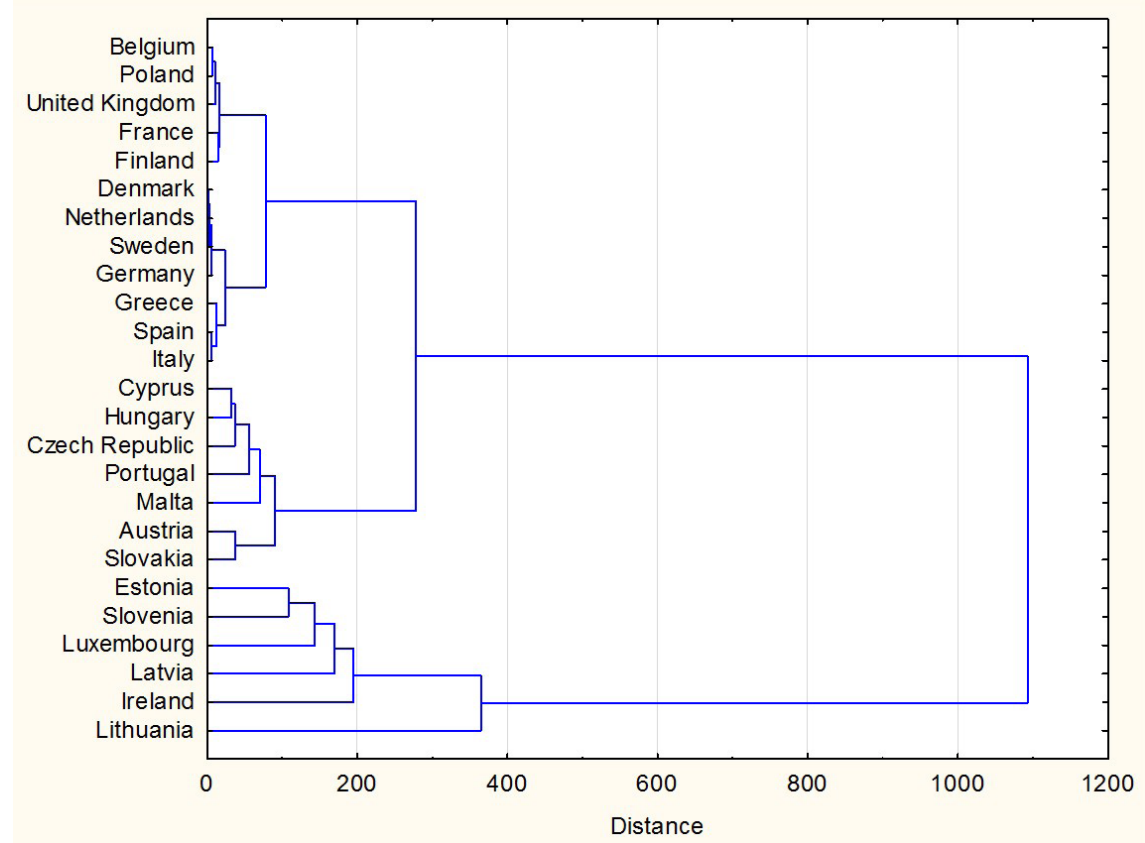

Source: FADN, Authors'own research

Figure 1: Dendrogram of EU Countries according to Investment Subsidies on Economic Size of a Company. 
seen in Cyprus (by - $2 \%$ ).

Group 4 (Estonia, Slovenia, Luxembourg, Latvia, Ireland, Lithuania), where investment subsidies are distinctly above average, nevertheless, in most of them the average inter-annual decrease can be seen, a slight increase can be noticed only in Luxembourg (by $5 \%$ ) and Latvia has zero investment subsidies in the last two years.

In view of the fact that the investment subsidies should be reflected in gross investment, in table 2 is tracing the evolution of gross investments converted into economic size (ESU) and again, the absolute values are complemented by an annual average increment.

Gross investments grew fastest in Bulgaria (37.8 €/ESU per annum), Lithuania (33.8), Estonia (23.9), Czech Republic (21.7), and Latvia (21.5) per annum, while the highest value of gross investments recalculated on the economic size of the enterprise was recorded in Luxembourg, the Baltics, Slovenia and in Austria. The decline in gross investments in agriculture is recorded in Poland, Denmark, Romania, Spain, Malta and Italy, while the lowest values are in Cyprus, Greece, Spain, Italy and Malta (Table 2).

According to the share of investment subsidies on gross investments, the EU states can be divided into 5 groups (Figure 2).

Group 1 (Belgium, UK, Finland) has the share of investment subsidies on gross investments slightly above the EU average and the trend is slightly dropping in the whole group and in the whole EU. The biggest dropping rate of this indicator can be seen in Finland (by $-15 \%$ annually).

Group 2 (the CR, Spain, France, Greece, Italy, Ireland) is characterized by slightly below-average share of investment subsidies on gross investments and the average growth rate is the highest in Greece $(11 \%)$, France and Ireland. The dropping trend can be seen in the CR, Spain and Italy.

Group 3 (Estonia, Slovenia, Hungary, Austria, Latvia, Luxembourg, Portugal) has a distinctly

\begin{tabular}{|c|c|c|c|c|c|c|c|c|c|c|c|}
\hline & 2004 & 2005 & 2006 & 2007 & 2008 & 2009 & 2010 & 2011 & 2012 & 2013 & $\begin{array}{c}\text { Average } \\
\text { increment }\end{array}$ \\
\hline Belgium & 121.6 & 134.7 & 163.3 & 200.3 & 192.0 & 187.8 & 176.0 & 200.5 & 160.3 & 196.3 & 8.30 \\
\hline Bulgaria & & & & 146.8 & 323.6 & 195.9 & 277.8 & 275.5 & 303.2 & 373.7 & 37.81 \\
\hline Cyprus & -6.0 & -2.1 & -38.8 & 39.0 & 13.6 & 192.2 & 39.4 & 38.7 & 90.9 & 31.4 & 4.15 \\
\hline Czech Republic & 81.7 & 105.6 & 134.3 & 156.7 & 183.7 & 131.2 & 140.6 & 226.2 & 253.9 & 276.7 & 21.67 \\
\hline Denmark & 309.0 & 389.5 & 390.9 & 435.2 & 442.1 & 211.3 & 169.8 & 204.2 & 197.3 & 246.6 & -6.93 \\
\hline Germany & 113.3 & 117.7 & 140.7 & 146.0 & 160.2 & 152.7 & 177.5 & 196.5 & 204.3 & 240.1 & 14.09 \\
\hline Greece & 31.7 & 36.1 & 49.3 & 45.9 & 32.8 & 34.8 & 39.2 & 23.4 & 47.6 & 33.8 & 0.23 \\
\hline Spain & 49.5 & 36.3 & 36.4 & 46.4 & 33.8 & 52.5 & 42.4 & 47.2 & 52.2 & 38.9 & -1.18 \\
\hline Estonia & 298.7 & 368.4 & 343.3 & 352.9 & 569.6 & 172.9 & 231.0 & 356.9 & 393.9 & 513.8 & 23.90 \\
\hline France & 185.7 & 182.0 & 166.6 & 182.3 & 206.8 & 169.5 & 159.1 & 179.4 & 193.3 & 196.3 & 1.18 \\
\hline Croatia & & & & & & & & & & 75.4 & \\
\hline Hungary & 132.8 & 123.4 & 117.5 & 172.0 & 162.0 & 187.8 & 116.0 & 159.4 & 143.4 & 174.3 & 4.61 \\
\hline Ireland & 150.4 & -87.0 & -67.9 & 290.1 & 435.2 & 162.7 & 78.7 & 233.0 & 221.4 & 305.3 & 17.21 \\
\hline Italy & 50.2 & 192.8 & 67.9 & 46.5 & 25.3 & 50.8 & 41.5 & 64.2 & 151.5 & 49.4 & -0.09 \\
\hline Lithuania & 186.2 & 309.0 & 514.6 & 457.4 & 596.5 & 423.3 & 450.8 & 510.8 & 477.1 & 490.4 & 33.80 \\
\hline Luxembourg & 437.0 & 387.1 & 392.4 & 410.5 & 435.2 & 342.4 & 491.1 & 522.1 & 704.4 & 583.2 & 16.25 \\
\hline Latvia & 349.1 & 542.2 & 538.5 & 531.4 & 641.3 & 185.7 & 168.8 & 437.9 & 514.9 & 542.7 & 21.52 \\
\hline Malta & 61.7 & 123.2 & 98.3 & 115.3 & -353.6 & 139.7 & 201.8 & 122.8 & 142.8 & 57.8 & -0.43 \\
\hline Netherlands & 167.7 & 176.9 & 180.8 & 244.8 & 200.7 & 205.5 & 177.9 & 218.0 & 217.2 & 189.5 & 2.42 \\
\hline Austria & 295.1 & 332.3 & 297.9 & 359.7 & 411.7 & 373.9 & 334.5 & 414.1 & 405.7 & 410.0 & 12.77 \\
\hline Poland & 352.6 & 161.7 & 194.8 & 218.2 & 202.5 & 144.4 & 155.9 & 149.4 & 202.2 & 169.0 & -20.40 \\
\hline Portugal & 163.6 & 136.7 & 128.0 & 148.4 & 93.3 & 82.5 & 119.9 & 110.3 & 161.4 & 172.7 & 1.01 \\
\hline Romania & & & & 102.4 & 58.8 & 97.5 & 67.3 & 52.2 & 79.0 & 83.0 & -3.24 \\
\hline Finland & 332.5 & 412.7 & 370.2 & 555.2 & 451.6 & 350.4 & 348.9 & 313.3 & 340.0 & 350.5 & 2.00 \\
\hline Sweden & 243.3 & 221.1 & 260.5 & 336.5 & 349.7 & 246.6 & 342.4 & 397.2 & 330.4 & 273.6 & 3.36 \\
\hline Slovakia & 123.7 & 181.5 & 116.0 & 235.7 & 368.2 & 260.5 & 192.2 & 271.7 & 230.3 & 224.2 & 11.16 \\
\hline Slovenia & 389.0 & 270.2 & 304.4 & 368.5 & 482.5 & 452.8 & 356.7 & 363.3 & 419.7 & 412.6 & 2.62 \\
\hline United Kingdom & 166.1 & 156.1 & 185.5 & 213.7 & 208.0 & 194.0 & 224.0 & 253.2 & 264.9 & 254.9 & 9.87 \\
\hline EU & 143.31 & 155.40 & 142.36 & 162.36 & 163.12 & 142.55 & 139.19 & 161.23 & 182.87 & 169.04 & 2.86 \\
\hline
\end{tabular}




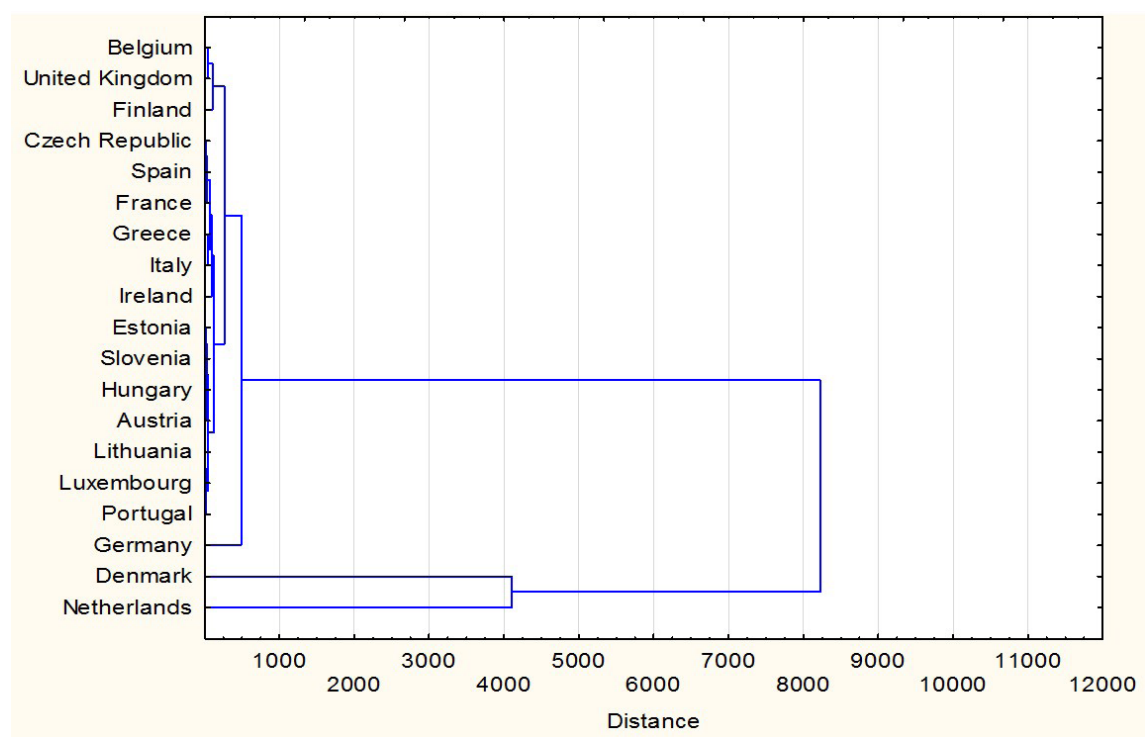

Source: FADN, Authors'own research

Figure 2: Dendrogram of EU States according to the Share of Investment Subsidies on Gross Investments.

below-average share of investment subsidies on gross investments and the dropping trend of this indicator is in Hungary, Luxembourg, and Portugal. On the contrary, growth of this indicator can be seen in Estonia, Latvia, Austria and in Slovakia.

Group 4 (Germany) shows above-average share of investment subsidies on gross investments and the trend is dropping by $5.8 \%$ a year.

Group 5 (Denmark, Netherlands) is characterized by a distinctly above-average share of investment subsidies on gross investments and the trend is dropping in Denmark by $10 \%$ a year and in Netherlands by $34 \%$ a year.

As an effect of investment subsidies can be expected with an increase in fixed assets and farm net income (relative to economic size - ESU). This analysis was utilized Figure 3, which includes the development of evaluated indicators. The figure has already presents summary of the results for the EU (because of the extent of the paper there are not presented data according to each country). However, there was also an assessment of these partial indicators in the various countries from which the following conclusions:

- The highest value of fixed assets recalculated on the economic size of enterprise is recorded in Ireland, the UK, Slovenia and Denmark while the lowest value is in Slovakia, France and Bulgaria. Slovakia also showed the highest decline in FixedAssets by an average of $12 \%$ per annum, a slight decline was recorded in Malta, Italy, Portugal and Slovenia. Lithuania, Poland and Slovenia show the highest increase in Fixed Assets.

- Farm Net Income (profit/loss) is variable in particular years, in the EU an average of FNI ranges from $226 € / E S U$ (2009) to $373 € / \mathrm{ESU}$ (2007). The negative values appear in most of the years in Slovakia and within 2008 - 2009 in Denmark. The average drop occurs in Malta (by 4\%), in Finland $(3.8 \%)$, in Estonia and Spain by $3.3 \%$, in Greece $(2.7 \%)$, Slovenia $(2.6 \%)$, Italy $(2.4 \%)$, Lithuania $(2.1 \%)$, France, Luxembourg, Austria and Belgium. The CR recorded an average growth of $8.5 \%$ per annum, but still below the EU average. The highest average profit growth per annum is recorded in Sweden (12\%), Hungary (10.5\%), Cyprus (9.5\%) and Romania $(9.4 \%)$.

The expected thesis was that the increase in investment subsidies leads to an increase in other indicators. The graph shows that the value of the investment subsidies is compared with other indicators significantly lower and therefore we cannot expect a similar development is monitored indicators.

In many countries, the investment subsidies have character renewal of obsolete assets (esp. NMS). Fixed assets bringing new technologies to enhance of productivity and thus income growth, some precision farming technologies are already a "superstructure". However, in terms 


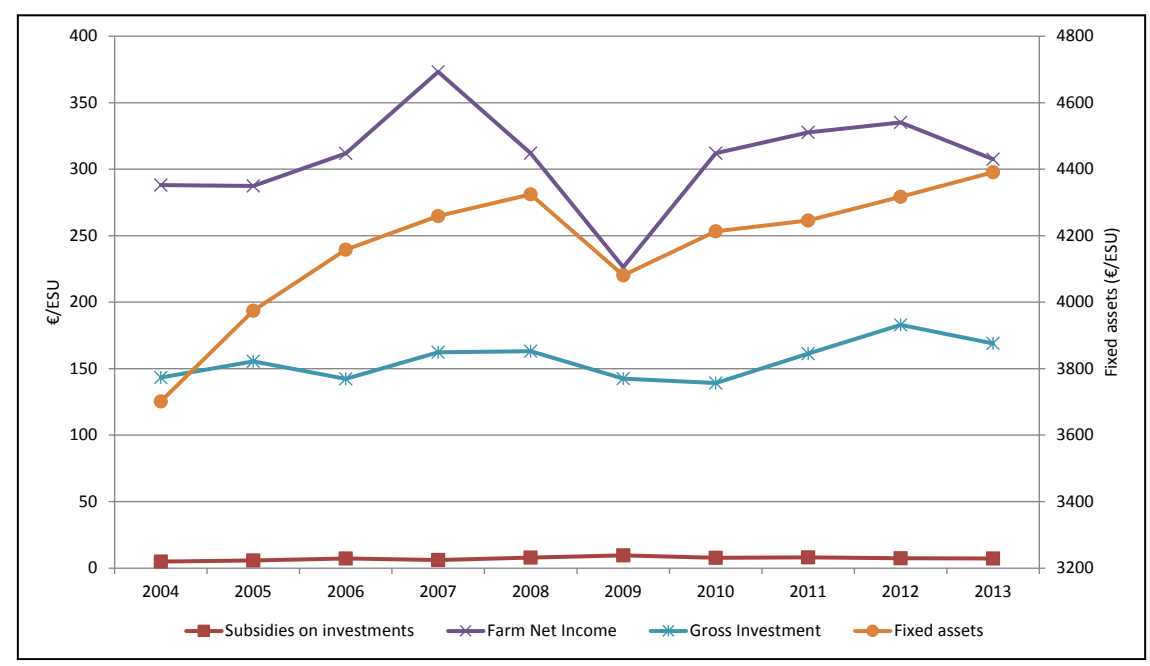

Source: FADN, Authors'own research

Figure 3: Development of monitored indicators - EU average.

of co-financing of this type of subsidy is for many farmers less available type of property. Therefore, these investment subsidies can contribute more to maintain their current income, eventually a little increase. It is understandable that the development of income is influenced by other factors (e.g. climatic conditions, price volatility).

Analysis of individual relations of monitored indicators and investment subsidies is further complemented by correlation. Considering the dependence of particular factors on subsidies on investments in each year, the lowest correlation coefficient and the lowest value of regression coefficient is in the relationship between fixed assets and subsidies on investment. The dependence of gross investments on subsidies on investment show the middle and higher dependency, i.e. $30-47 \%$ of gross investment changes can be explained by the change of subsidies of investments. An increase in subsidies on investments by $1 €$ has meant an increase in gross investments by $4.5-1.2 €$. The correlation coefficient of investment subsidies influence on Farm Net Income indicates low values which have significantly reduced in the last two years. It is therefore possible to conclude that the amount of subsidies on investment doesn't significantly affect the amount of Farm Net Income.

The lowest correlation coefficient in individual countries is in the relation of investment subsidies and Farm Net Income. Only in Romania does the dropping trend of investment subsidies and growing trend of profit result in negative dependence. The highest positive correlation between subsidies on investment and FNI is in Denmark, where an increase in investment subsidies by $1 €$ will increase profits by $115 €$. The dependence of gross investments on investment subsidies was proven in Cyprus, in the CR, in Germany, in Hungary and in the UK. For example, in Germany $89 \%$ of changes in gross investments can be explained by the change in investment subsidies. On the contrary, in Sweden the negative correlation is caused by the fact that investment subsidies have been zero in the last four years. The lowest value of regressive coefficient is in the relation of investment subsidies and fixed assets. The dependence of fixed assets on investment subsidies is evident in the CR, Finland, Germany, Luxembourg and Poland. In these countries 41 to $84 \%$ of changes in fixed assets can be explained by the change in investment subsidies. The increase of investment subsidies by $1 €$ meant the increase of fixed assets by $220 €$ in Poland and by $187 €$ in Germany. The decreasing trend of fixed assets in Slovakia and coincident increase of investment subsidies result in negative dependence, therefore, the increase of investment subsidies by $1 €$ means the decrease of fixed assets by $52 €$.

The Correlation matrix implies (Table 3 ) that gross investments recalculated to the economic size of a company depend on investment subsidies $(r=0.581)$, the negative dependence was proved in the share of subsidies on income $(r=-0.215)$, in the share of subsidies on fixed assets $(r=-0.180)$ and share of subsidies on gross investments $(r=-0.168)$. In the case of Farm Net Income, the highest dependence proved as a negative dependence on the share of subsidies on gross 


\begin{tabular}{|l|c|c|c|c|c|c|c|}
\hline \multicolumn{1}{|c|}{ Variable } & $\begin{array}{c}\text { Investment } \\
\text { subsidy }\end{array}$ & Income & $\begin{array}{c}\text { Gross } \\
\text { Investments }\end{array}$ & $\begin{array}{c}\text { Fixed } \\
\text { Assets }\end{array}$ & $\begin{array}{c}\text { Income/ } \\
\text { Subsidies }\end{array}$ & $\begin{array}{c}\text { GI/ } \\
\text { Subsidies }\end{array}$ & $\begin{array}{c}\text { FA/ } \\
\text { Subsidies }\end{array}$ \\
\hline Investment Subsidies & 1 & 0.193 & 0.581 & 0.062 & -0.215 & -0.168 & -0.180 \\
\hline Income & 0.193 & 1 & -0.061 & 0.217 & 0.214 & -0.255 & -0.196 \\
\hline Gross Investments & 0.581 & -0.061 & 1 & 0.006 & -0.229 & 0.008 & -0.058 \\
\hline Fixed Assets & 0.062 & 0.217 & 0.006 & 1 & -0.016 & 0.019 & 0.074 \\
\hline Income/Subsidies & -0.215 & 0.214 & -0.229 & -0.016 & 1 & 0.542 & 0.585 \\
\hline GI/Subsidies & -0.168 & -0.255 & 0.008 & 0.019 & 0.542 & 1 & 0.951 \\
\hline FA/Subsidies & -0.180 & -0.196 & -0.058 & 0.074 & 0.585 & 0.951 & 1 \\
\hline
\end{tabular}

Note: Marked correlations are significant at $\mathrm{p}<0.01, \mathrm{~N}=265$ (Casewise deletion of missing data) Source: FADN, Authors'own research

Table 3: Correlation Matrix of Monitored Indicators.

investments $(r=-0.255)$. The size of fixed assets depends only on the size of Farm Net Income $(r=0.217)$. The share of investment subsidies on the income depends on the share of investment subsidies on gross investments $(r=0.542)$ and on the share of investment subsidies on fixed assets $(r=0.585)$. The share of subsidies on gross investments shows the most significant dependence $(r=0.951)$ with the share of investments subsidies on fixed assets.

\section{Conclusion}

The support of investment subsidies represents not only possibilities for extending new property, but in many cases, (especially in post-transforming countries like Poland, the CR and Bulgaria with the highest growth rate of investment subsidies 20-36\%) also a return of written-off assets.

As a consequence of their becoming outdated, they do not bring necessary profits and also from the technological viewpoint they are inconvenient. The average of investment subsidies recalculated to the economic size of a company increased in the EU during the monitored period from 4.93 to $7.22 € / \mathrm{ESU}$, i.e. one and a half times. This fact undoubtedly influences also the highest rate of gross investments of these countries (e.g. Bulgaria $17 \%$, the CR $14.5 \%$ ). On the other hand, there are countries whose values of assets are at a high level (e.g. Ireland, the UK) although investments subsidies do not reach such values - growth rate, volume. It is obviously caused by the general economic level of these countries where the investment growth is not so dependent on provided subsidies.

Especially the economically more advanced countries (Germany, Denmark, Sweden) amounting to investment subsidies per ESU below average or average in the EU - i.e. 5 - $9.5 € / \mathrm{ESU}$ in the period. On the contrary, the Baltic countries or V4 countries acquired higher investment subsidies than the EU average in most of the monitored years.

The dependence of gross investments on investment subsidies shows medium and higher dependence, i.e. $30-47 \%$ of changes in gross investments can be explained by a change of investment subsidies. The dependence of gross investments on investment subsidies was proven in Cyprus, in the CR (45\% of changes in gross investments result from a change of investment subsidies), in Germany, Hungary, and the UK. According to the share of investment subsidies on gross investments, the EU states were divided into 5 groups and most states belong to groups with below-average values (the EU average in monitored years oscillates between $15 \%$ and $29 \%$ ). The above-average values of the share of investment subsidies on fixed investments are reached by Germany, Denmark, and Netherlands.

The correlation coefficient of the influence of investment subsidies on the Farm Net Income has low values, which have been dropping considerably in the last two years. Thus, it is possible to state that the size of investment subsidies does not influence the size of Farm Net Income considerably or does not influence a current profit; therefore, the size of subsidies on investments will probably prove with a delay. The dependence of impact of investment subsidies on fixed assets is apparent in the CR, Finland, Germany, Luxembourg and Poland.

\section{Acknowledgements}

The authors thank the Ministry of Education of the Czech Republic for financial support, Research Program of the Department of Accounting and Finance (RVO160). 
Corresponding author:

Ing. Jana Lososová

Department of Finance and Accounting, Faculty of Economic,

University of South Bohemia in České Budějovice

Studentská 13, 37005 České Budějovice, Czech Republic

E-mail:lososova@ef.jcu.cz

\section{References}

[1] Bergschmidt, A. (2009) "Powerless Evaluation”, EuroChoices, No. 8, pp. 37-42. ISSN 1746-692X. DOI 10.1111/j.1746-692X.2009.00137.x.

[2] Blandford, D., Boisvert, R. N. and Hill, B. (2010) "Improving the Evaluation of Rural Development Policy”, EuroChoices, No. 9, pp. 4-9. ISSN 1746-692X. DOI 10.1111/j.1746-692X.2010.00147.x.

[3] Bradley, D., Dwyer, J. and Hill, B. (2010) "The Evaluation of Rural Development Policy in the EU", EuroChoices, No. 9, pp. 15-20. ISSN 1746-692X. DOI 10.1111/j.1746-692X.2010.00148.x.

[4] Forstner, B. (2000) "Erfolgskontrolle der einzelbetrieblichen Investitionsförderung in der Landwirtschaft", In: Schriften der Gesellschaft für Wirtschafts- und Sozialwissenschaften des Landbaues e.V, Münster-Hiltrup: Landwirtschaftsverlag, Vol. 36(2000), pp. 151-158. ISBN 3-7843-3065-7.

[5] Giannakis, E. and Bruggeman, A. (2015) "The highly variable economic performance of European agriculture", Land Use Policy, Vol. 45, pp. 26-35. ISSN 0264-8377.

[6] Kirchweger, S. and Kantelhardt, J. (2015) "The dynamic effects of government-supported farm-investment activities on structural change in austrian agriculture", Land use Policy, Vol. 48, pp. 73-93. ISSN 0264-8377.

[7] Hoffmann, H., Jahnke, D. and Kögl, H. (1997) "Effektivität der investitionsförderung", Rostocker Agrar- und Umweltwissenschaftliche Beiträge, Vol. 6, pp. 179-201. ISSN 0945-4624.

[8] Lakner, S. (2009) "Technical efficiency of organic milk-farms in Germany - The role of subsidies and of regional factors", IAAE 2009 Conference, 16-22 August, Beijing. [Online]. Available: http://ageconsearch.umn.edu/bitstream/51301/2/638.pdf [Accessed: 3 Sep. 2016].

[9] Latruffe, L., Guyomard, H. and Le Mouël, C. (2009) "The Role of Public Subsidies on Farms' Managerial Efficiency: An Application of a Five-Stage Approach to France”, Working Paper SmartLereco, No. 09-05, INRA, Rennes. [Online]. Available: http://www6.rennes.inra.fr/smart_eng/ Archive-publications/Working-Papers/Working-papers-2009 [Accessed: 10 May. 2016].

[10] Lucian, P. (2014) “Absorption of European Funds by Romania”, Procedia Economics and Finance, Vol. 16, pp. 553-556. DOI 10.1016/S2212-5671(14)00838-7.

[11] Margarian, A., Blandford, D. and Hill, B. (2010) "A Theoretical Foundation of Rural Development Interventions and Evaluations is Needed", EuroChoices, Vol. 9, pp. 35-39. ISSN 1746-692X. DOI 10.1111/j.1746-692X.2010.00166.x

[12] Mary, S. (2013) "Assessing the impacts of pillar 1 and 2 subsidies on TFP in French crop farms", Journal of Agricultural Economics, Vol. 64, No.1, pp.133-144. ISSN 1477-9552.

[13] Michalek, J., Ciaian, P., and Kancs, D. (2016) "Investment crowding out: Firm-level evidence from northern Germany", Regional Studies, Vol. 50, No. 9, pp. 1579-1594. DOI 10.1080/00343404.2015.1044957.

[14] OECD (2006) "The New Rural Paradigm: Policies and Governance”, OECD Rural Policy Reviews, Organisation for Economic Co-operation and Development (OECD), Paris 2006. ISBN 9264023917.

[15] OECD (2001) "Decoupling: A Conceptual Overview", Paris: OECD, 2001. [Online]. Available: https://www.oecd.org/tad/agricultural-policies/25481500.pdf [Accessed: 10 May. 2016]. 
[16] O'Toole, C., and Hennessy, T. (2015) "Do decoupled payments affect investment financing constraints? evidence from irish agriculture", Food Policy, Vol. 56, pp. 67-75. DOI 10.1016/j.foodpol.2015.07.004.

[17] Rencher, A. C. (2002) “Methods of Multivariate Analysis" (2 $2^{\text {nd }}$ ed.). Hoboken: Wiley. 2002. ISBN 0-471-41889-7.

[18] Řezanková, H., Húsek, D., and Snášel, V. (2009) "Shluková analýza dat" (Cluster data analysis - in Czech), (2 $2^{\text {nd }}$ ed.), Prague 2009, Professional Publishing. ISBN 978-80-86946-81-8.

[19] Richardson. T. (2000) "Discourses of rurality in EU spatial policy: the European spatial development perspective”, Sociologia Ruralis, Vol. 40, No. 1, pp. 53-71. DOI 10.1111/1467-9523.00131.

[20] Rizov, M., Pokrivcak, J., and Ciaian, P. (2013) "CAP subsidies and productivity of the EU farms", Journal of Agricultural Economics, Vol. 64, No. 3, pp. 537-557. ISSN 1477-9552. DOI 10.1111/1477-9552.12030.

[21] Sckokai, P. and D. Moro (2009) "Modelling the impact of the CAP Single Farm Payment on farm investment and output", European Review of Agricultural Economics, Vol. 36, No. 3, pp. 395-423. ISSN 1464-3618.

[22] Shucksmith, M., Thomson, K.J., and Roberts D. (2005) "The CAP and The Regions: The Territorial Impact of the Common Agricultural Policy”, EuroChoices, No. 5, pp. 42-44. ISSN 1746-692X. DOI 10.1111/j.1746-692X.2006.00026.x.

[23] Svoboda, J., Lososová, J. and Zdeněk, R. (2015) “Analysis of Operating Costs of Subsidies in the Field of Agriculture of EU Countries", Agrison-Line Papers in Economics and Informatics, Vol. VII., No. 4, pp. 161 - 173. ISSN 1804-1930.

[24] The Farm Accountancy Data Network (2016) "Standard results". [Online]. Available: http://ec.Europa.eu/agriculture/rica/database/consult_std_reports_en.cfm [Accessed: 4 Febr. 2016].

[25] Viaggi, D., Raggi, M., and Paloma, S. G. Y. (2011) "Understanding the determinants of investment reactions to decoupling of the common agricultural policy", Land use Policy, Vol. 28, No. 3, pp. 495-505. DOI 10.1016/j.landusepol.2010.10.003.

[26] Yee, J., Ahearn, M. and Huffman, W. (2004) "Links among farm productivity, off-farm work, and farm size in the Southeast", Journal of Agricultural and Applied Economics, Vol. 36, No. 3, pp. 591-603. ISSN 1074-0708. DOI 10.1017/S1074070800026882.

[27] Zasada, I., Reutter, M., Piorr, A., Lefebvre, M., and Gomez y Paloma, S. (2015) "Between capital investments and capacity building-Development and application of a conceptual framework towards a place-based rural development policy", Land Use Policy, Vol. 46, No. 6, pp. 178-188. ISSN 0264-8377. 